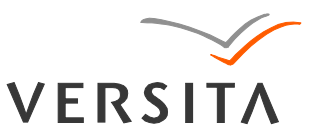

GEOCHRONOMETRIA 40(3) 2013: 208-216

DOI 10.2478/s13386-013-0113-x

Available online at

www.springerlink.com

\title{
HUMAN-PLANTED ALDER TREES AS A PROTECTION AGAINST DEBRIS FLOWS (A DENDROCHRONOLOGICAL STUDY FROM THE MOXI BASIN, SOUTHWESTERN CHINA)
}

\author{
IRENEUSZ MALIK ${ }^{1,2}$, YONGBO TIE ${ }^{2}$, PIOTR OWCZAREK ${ }^{3,2}$, MALGORZATA WISTUBA $^{1}$, \\ WOJCIECH PILORZ ${ }^{1}$ and BEATA WOSKOWICZ-ŚLEZZAK ${ }^{1}$ \\ ${ }^{I}$ Department of Reconstructing Environmental Change, Faculty of Earth Sciences, University of Silesia, \\ ul. Będzińska 60, 41-200 Sosnowiec, Poland \\ ${ }^{2}$ Chengdu Centre of China Geological Survey, State Key Laboratory of Geohazard Prevention and Geoenvironment Protection, \\ Chengdu University of Technology, No. 2 of N-3-Section of First Ring Road, Chengdu, China \\ ${ }^{3}$ Institute of Geography and Regional Development, University of Wroclaw, \\ pl. Uniwersytecki 1, 50-137 Wroctaw, Poland
}

Received 9 December 2012

Accepted 16 April 2013

\begin{abstract}
Large debris flows have destroyed the infrastructure and caused the death of people living in the Moxi Basin (Sichuan Province, Southwestern China). Inhabitants of the Moxi Basin live on the flat surfaces of debris-flow fans, which are also attractive for farming. During the monsoon season debris flows are being formed above the fans. Debris flows can destroy the houses of any people living within the fan surfaces. In order to prevent the adverse effects of flows, people plant alder trees (Alnus nepalensis) at the mouths of debris flow gullies running above debris flow fans. Alders are able to capture the debris transported during flow events. Trees are well adapted to surviving in conditions of environmental stress connected with abrupt transport and deposition of sediment from debris flows. Numerous wounds, tilting and bending of alder trees caused by debris flows only very rarely cause the death of trees. By dating scars and dating the time of alder tilting (through the analysis of annual rings), we have determined the frequency of debris flows occurring at the mouth of the Daozhao valley. In 1980-2012 within the studied debris-flow fan and the Daozhao gully, 2 large debris flow events occurred $(1996,2005)$ and some smaller events were probably recorded every 2-3 years.
\end{abstract}

Keywords: debris flow; dendrochronology; tree wound dating; eccentric growth of trees dating; South-Western China.

\section{INTRODUCTION}

Debris flows mainly develop as a result of heavy rainfalls, which are usually short-lasting (Caine, 1980; Reid et al., 1988; Kotarba, 1992; Fiorillo and Wilson, 2004).

Corresponding author: I. Malik

e-mail: irekgeo@wp.pl
They also develop as a consequence of snow melts (Bardou and Delaloye, 2004; Decaulne et al., 2005), and their appearance can also be intensified by earthquakes occurring at the same time as strong rainfalls (Lin et al., 2003; Tang et al., 2012). Recently, due to the rapid melting of glaciers, we have observed an increase in debris flow occurrence in high-mountain areas (Chiarle et al., 2007). Because of this, more and more attention is being devoted 
to different ways of preventing the adverse effects of debris flow occurrence. New methods are being developed for predicting and mitigating against debris flow events (Berti and Simoni, 2007; Miller and Burnett, 2008; Conway et al., 2010).

Most of the debris flow events are initiated above timberlines or in other areas where there is a lack of dense forest cover. A reduction in event energy is observed when debris flows enter forests. The suppression of debris flow movement by forests and the influence of trees on the shape of debris flow has been reported in a few research papers (May, 2002; Ishikawa et al., 2003, Lancaster and Hayes, 2003, Matyja, 2007; Malik and Owczarek, 2009; Šilhán and Pánek, 2010).

Debris flows are a widespread and frequent phenomenon causing extensive damage in south-western China, particularly in the Sichuan Province, where the studies presented in this paper were carried out. This area is referred to as both "the land of abundance" and the "geological disasters museum" (Dai, 2002; Yan and Yue, 2004). Several debris-flow events were recorded recently in Southwestern China. These debris flows have threatened and destroyed the local infrastructure and caused the death of people (Tang et al., 2012a, 2011). Therefore

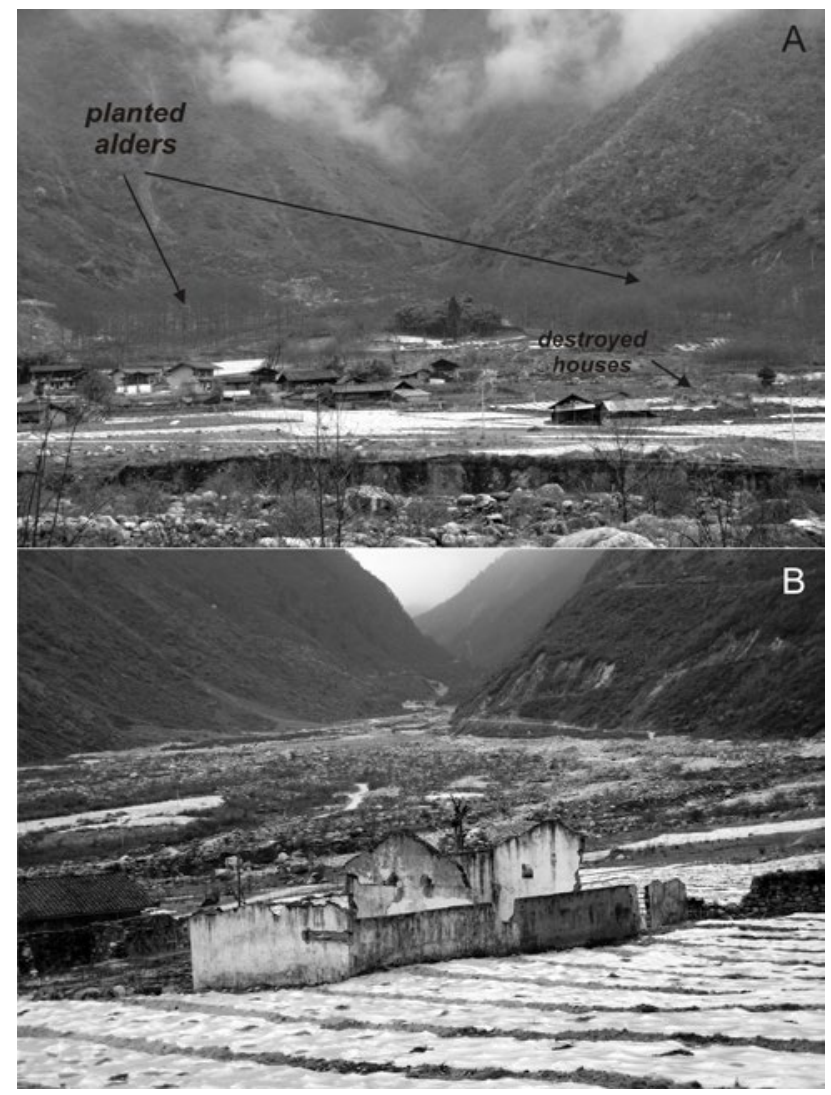

Fig. 1. The debris flow fan under study, (A) - the village is located on the debris flow fan and the planted alders are marked with arrows, (B) - one of the houses destroyed by debris flows. prediction and mitigation of debris flows in the area is particularly important (Tang et al., 2012b; Tie, 2013).

The people living in the mountainous areas of Sichuan Province often occupy small debris-flow fans located at the foot of gullies formed in loose moraine sediments (Fig. 1A). The debris flows which develop in these areas destroy houses and threaten human lives (Fig. 1B). Local people plant Alnus nepalensis saplings on fan surfaces in order to protect their villages from destruction by debris flows (Fig. 2A). Alder trees growing within the fans are being wounded and tilted by the debris transported during flows. At the same time, the trees slow the movement of debris flows and capture a portion of the debris, thus protecting people and their houses (Fig. 2B). This creates an opportunity for carrying out dendrochronological studies on human-planted alder specimens.

Dendrochronological dating is increasingly frequently used in geomorphic studies (e.g. Zielonka et al., 2009; Zielonka and Dubaj, 2010; Migoń et al., 2010; Malik and Wistuba, 2012; Šilhán, 2012; Šilhán et al., 2012). The debris flow phenomenon is often investigated by analysing the ring width and wood anatomy of affected trees (Baumann and Kaiser, 1999; Malik, 2004; Stoffel et al., 2005; Hrádek and Malik, 2007; Malik and Matyja, 2008;

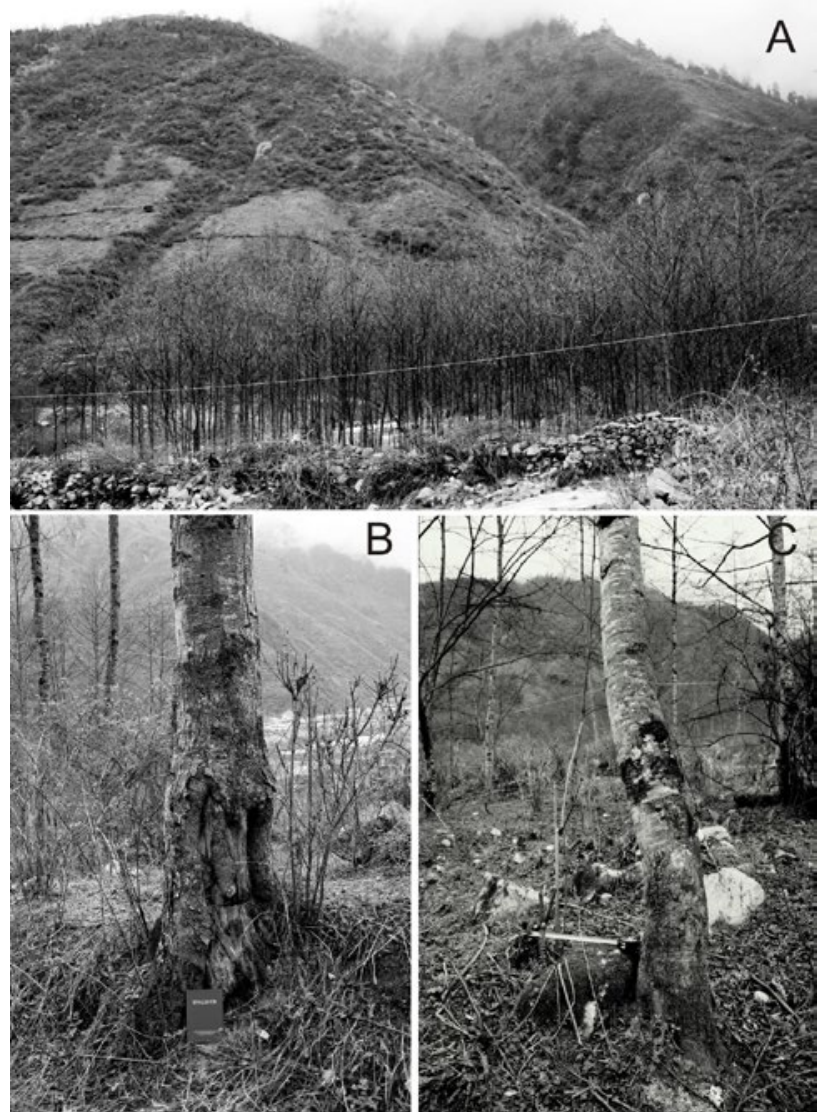

Fig. 2. Alders growing on fan under study, (A) - an alder plantation, (B) - an alder specimen wounded by a debris flow, (C) - an alder specimen tilted by a debris flow. 
Malik and Owczarek 2009; Stoffel, 2010; Bollschweiler et al., 2011; Lopez Saez et al., 2011; Procter et al., 2011). Commonly used dendrochronological markers in this type of study include an abrupt reduction in tree ring width, growth release and scars, as well as in the age of adventitious roots.

The aim of the study was to determine the role played by planted alders in the protection of settlements and people living within relatively small debris flow fan. This objective was realised by:

1) estimating the amount of trees capturing debris transported during flow episodes,

2) determining the frequency of debris-flow episodes by dendrochronological dating of wounds in trees and dendrochronological dating of stem tilting/bending using an eccentricity index of tree growth,

3) determining the ways in which alder trees adapt to growth in conditions of debris flow occurrence.

\section{THE STUDY AREA}

The study site is located within the Moxi Basin, Sichuan Province, Southwestern China (Fig. 3A). This area is under a fast tectonic uplift (approximately $2 \mathrm{~mm}$ per year), which is the most important reason for the occurrence of intensive erosion and drainage pattern changes in the study area (Fielding, 1996; Clark et al., 2004). Fast temperate glaciers retreat in the monsoonal climate zone and high discharges determine the increasing river incision and slope instability (Su Z and Shi Y, 2002; Li et al., 2010a). Due to this, valleys in the Moxi Basin are deep and have steep slopes. Tectonic activity and intensive precipitation cause the development of numerous debris flows and landslides in the study area.

The research area is located in the temperate monsoon region with a semi-humid climate (Leber et al., 1995). It is characterized by a cool, wet summer season and a cold, dry winter season. The climatic characteristics of the area are influenced by the south-eastern monsoon and warm humid current from Sichuan basin. The yearly average temperature in Garze (40 km north from Moxi Basin) is $6.2^{\circ} \mathrm{C}$; and the yearly average precipitation is $631 \mathrm{~mm}$, but the vast majority of rainfalls occur between June and September (Fig. 4). The amount of precipitation distinctly increases in the highest parts of the research area (Minya Konka massif) and reaches 1000-3000 mm/year (maximum in August - c. $325 \mathrm{~mm} / \mathrm{month}$ ) (Li Z et al. 2010b).

In order to conduct an in-depth study, we selected a debris flow fan located at the mouth of a gully named Daozhao (Fig. 3B). The northern part of the fan is occupied by small Zhetianba village. The bedrock in the study area is composed of Permian age granite. In the catchment where the investigated debris flow gully and fan are located, the bedrock is mainly composed of glacial deposits (mainly loamy, poorly sorted moraine deposits) from the Pleistocene and Holocene (Tie, 2013). The valley head of the gully under study is located $3675 \mathrm{~m}$ a.s.l., while the debris fan is located between 2020 and $2131 \mathrm{~m}$ a.s.l. (Fig. 3). The gully is $c .4 \mathrm{~km}$ long, with an average slope of $31.5 \%$. The debris-flow fan under study is $731 \mathrm{~m}$ long and $1100 \mathrm{~m}$ wide at its broadest point. Its average inclination is $10.1 \%$. The total area of the fan is $0.34 \mathrm{~km}^{2}$. A different generation of debris flow tracks are clearly visible in the relief of the investigated alluvial fan (Fig. 5). The debris flow sediments are up to $20 \mathrm{~m}$ thick. The debris fan is being undercut by the Yajiageng River. Within the river bank, in the cross-profile, debris accumulated during different phases of gully activity and fan formation can be seen. These are separated by soil horizons (Fig. 6).

The vegetation covers about $60 \%$ of the Daozhao drainage basin. This is mostly composed of shrubs and bamboos. On the debris-flow fan, human-planted Alnus nepalensis are growing. These alder trees were planted
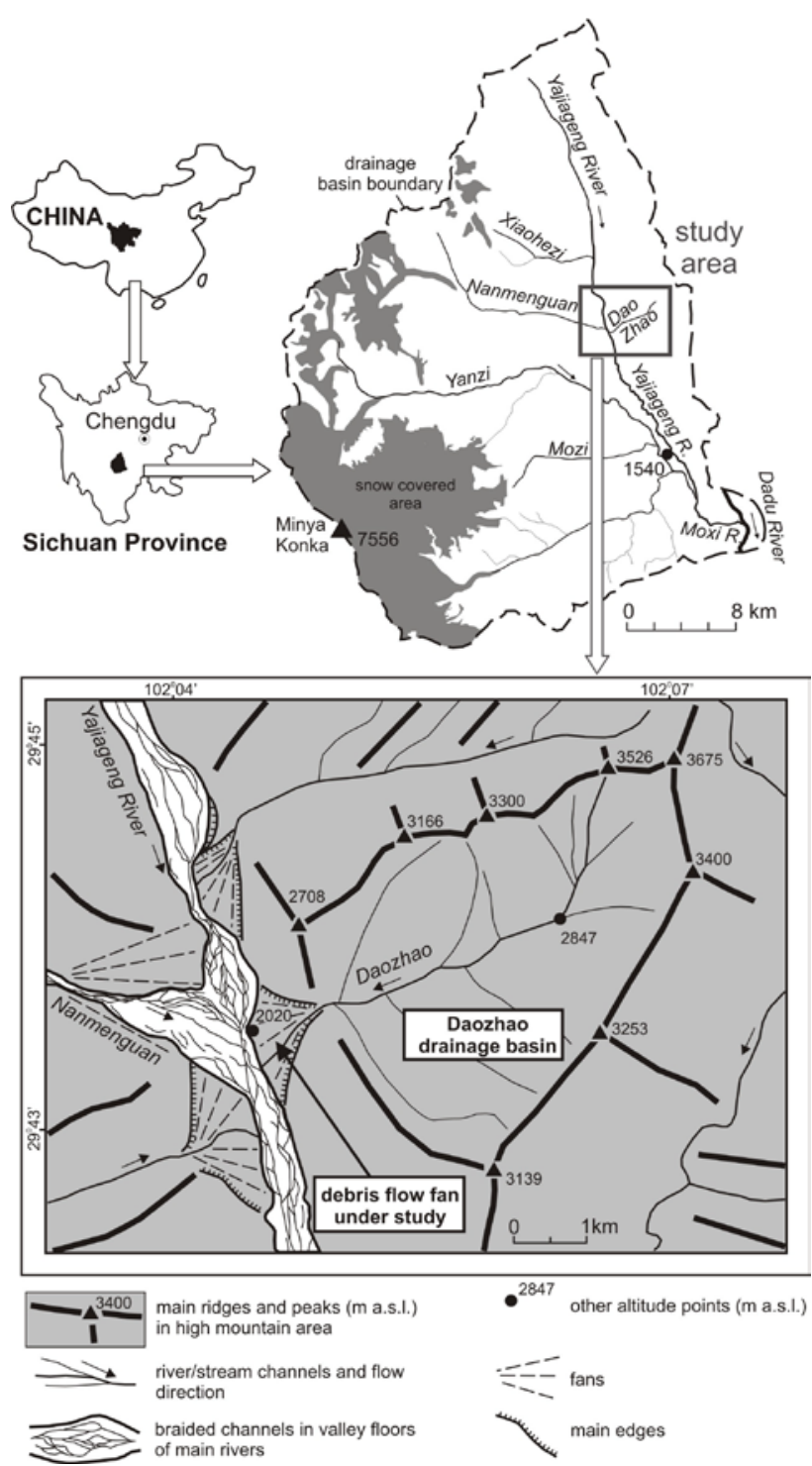

Fig. 3. Location of the area under study. 


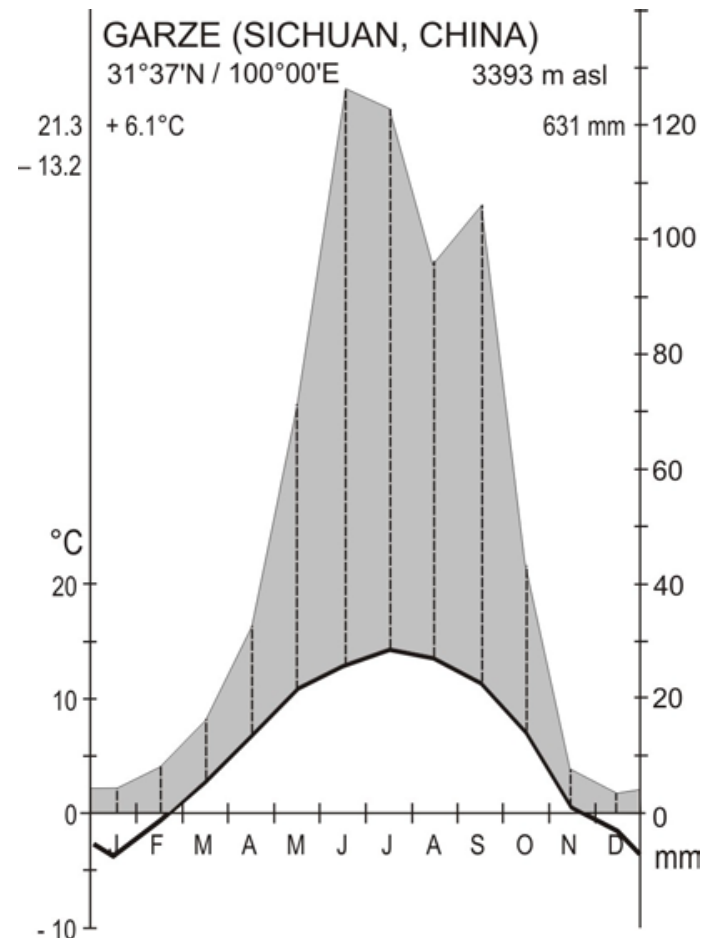

Fig. 4. Climatic diagram of the Garze meteorological station $(40 \mathrm{~km}$ to the north of the area under study).

over a few stages. The groups of alder trees growing within the fan are of equal age, which suggests they were planted by man. Closer to the gully, older trees are growing. Farther from the gully, near the village, younger alders were found. This was confirmed by local people living in the village located on the debris fan.

\section{MATERIAL AND METHODS}

\section{Capturing debris flow material recorded in the mor- phology of alder trees}

Trees are growing within an area of $0.09 \mathrm{~km}^{2}$. For the purposes of conducting a detailed study, we chose an area of $0.02 \mathrm{~km}^{2}$ (Fig. 5). In this area, we counted the trees which captured debris material. We assumed that alders were able to capture debris transported through the fan if their stems were buried under sediment and, additionally, at least two boulders were lying within a distance of less than $1 \mathrm{~m}$ from the stem. This attempt enabled us, in all probability, to determine the minimal amount of trees which capture coarse debris during debris-flow events. The presence of one boulder near a tree and the presence of more than one boulder within a distance of more than $1 \mathrm{~m}$ from a tree did not, in my opinion, provide sufficient proof of the role of tree-stems in capturing debris.

We also counted alders with tilted and wounded stems in the area of detailed study. We only took into consideration trees which were tilted in accordance with the slope inclination and thus the direction of debris flow move-

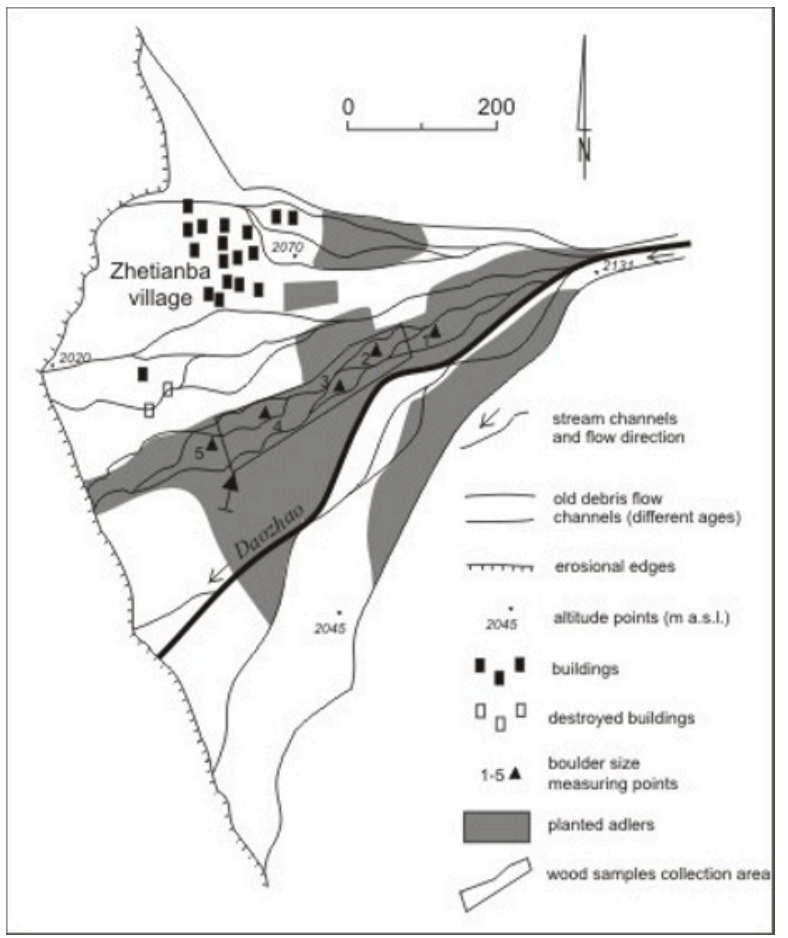

Fig. 5. Geomorphic sketch of the alluvial fan analyzed; the arrow indicates the wood sample collection area.

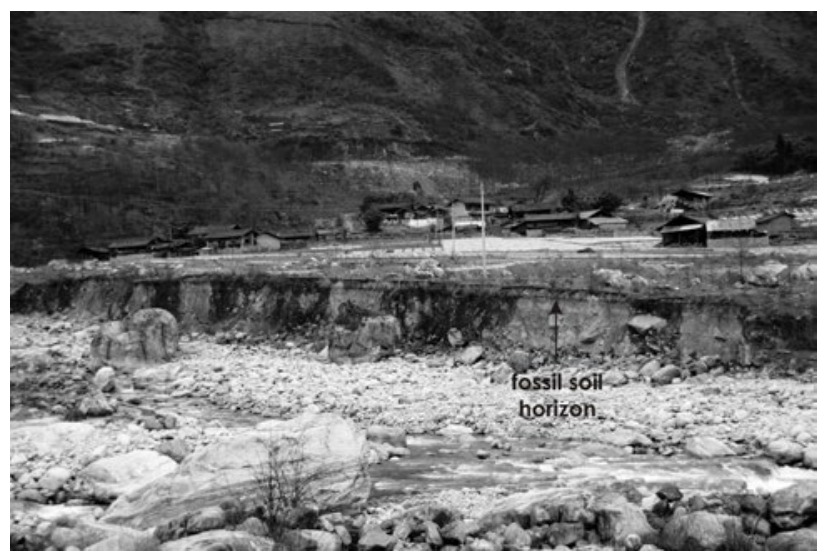

Fig. 6. The horizon of fossil soil as evidence for the occurrence of at least a few stages of debris deposition within the fan under study.

ment. We have only counted the wounds of stems located in the opposite direction to debris flow movement (upslope). This strategy enabled us to eliminate tilting and wounding caused by factors other than debris flows, e.g. wind, which can break neighbouring trees. We measured the length of every wound. We divided wounds into two groups on the basis of their size: small (less than $15 \mathrm{~cm}$ long) and big (more than $15 \mathrm{~cm}$ long). We also counted alders with broken stems, which were growing within the study site. We measured the longest axes of boulders at 5 points located along the debris flow tracks. 
We decided to measure only the 15 biggest boulders at each of the 5 selected locations (measuring points - Fig. 5).

\section{The frequency of debris flow events recorded in the tree rings of alder stems}

We took cores from 30 tilted and wounded alder trees growing on the debris flow fan (Fig. 5). From each tree, we collected at least 3 cores at breast height. One core was always collected from the middle of the wound/scar, the second $-5 \mathrm{~cm}$ above the wound/scar and the third, perpendicular to the wound/scar (Fig. 7). In the case of some trees, in which the three cores we had collected earlier were broken or damaged due to uneven wood density, we collected additional cores $5 \mathrm{~cm}$ below the wound/scar. 114 cores in total were collected from trees growing on the debris flow fan under study. Ring widths were measured in all the collected cores using the LinTab measuring system and TSAPWin Professional 4.65 software. Cores collected from individual trees were crossdated for wound dating. We used visual comparison and
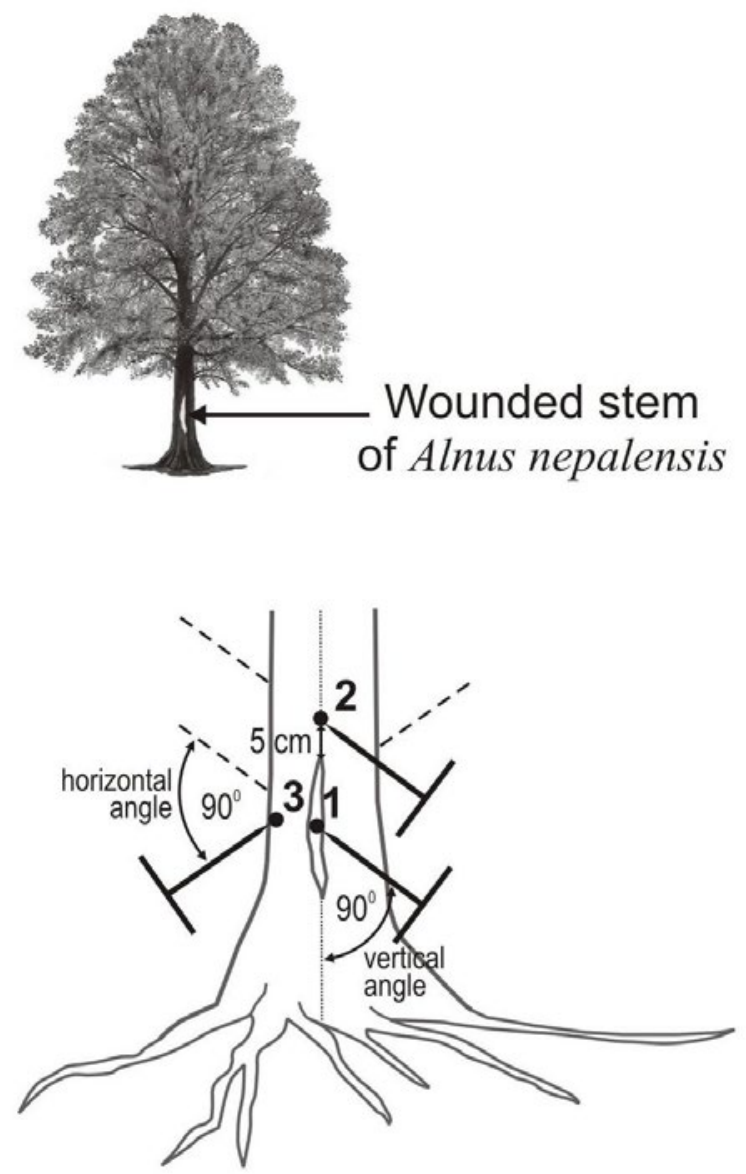

Fig. 7. The method of taking samples (cores) from alder stems, (1) - a core extracted from the middle of the scar, (2) - a core extracted $5 \mathrm{~cm}$ above a scar, (3) - a core extracted perpendicularly to a scar. skeleton plots (Zielski and Krapiec, 2004), a method of pointing distinctive years (narrower or wider than neighbouring rings, or years with some diagnostic anatomical features e.g. tension wood) on a calibrated sheet of paper. It allows precise cross-dating of individual ring series. Skeleton plots were prepared for cores from individual trees and compared for dating wound/scars.

Eccentricity index calculation was applied to the date tilting of alder trees. The method has been described in detail by Malik and Wistuba (2012). It is based on the assumption that tilted trees (deformed by a debris flow event) produce wider rings on one side of the stem and narrower rings on the other - i.e. that eccentric growth occurs (Fig. 8). The first year of eccentric growth directly dates an episode of tree tilting and indirectly, debris flow occurrence. Sometimes eccentricity occurs more than once in one tree ring curve, which means that the tree was tilted more than once.

\section{RESULTS}

A total of 1250 alder trees are growing within the area studied in detail. 1062 of them (85\%) are tilted and/or wounded by transported debris material. We found 137 wounded trees, 502 tilted trees and 423 both tilted and wounded alder trees. Within the area of detailed investigation, we only found nine broken alder trees.

It was found that $24 \%$ of analysed alder trees had captured coarse debris during past flow events (Fig. 9). The diameter of boulders rapidly decreases in the alder forest along the debris flow tracks. In the upper part of the fan, the average diameter of the rock particles reaches $145 \mathrm{~cm}$ (measuring point 1), whereas in the central and lower parts it only reaches $40-30 \mathrm{~cm}$ (points 4-5); (Table 1).

The average number of rings in cores sampled on the breast height is 17.5 and varies from 9 up to 30 . This

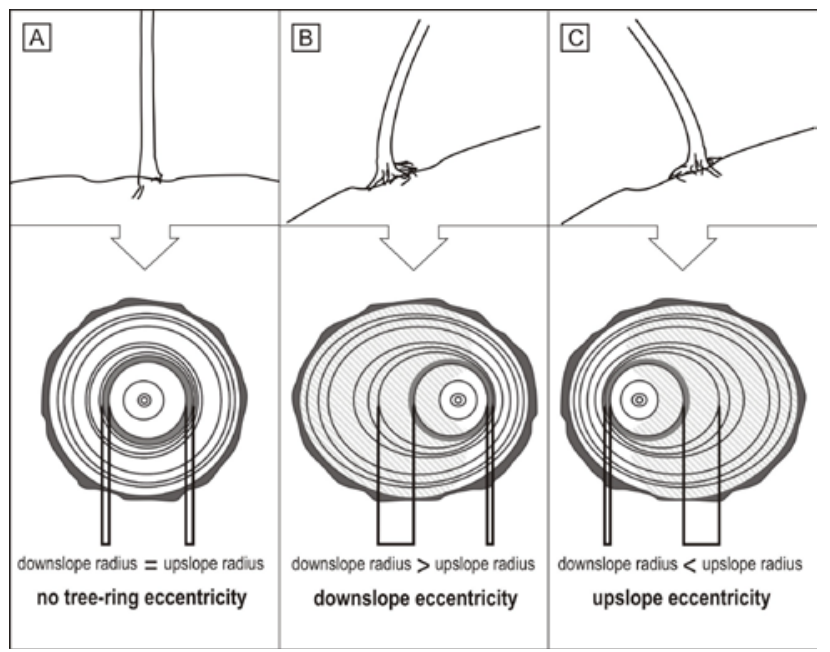

Fig. 8. Tree-ring eccentricity in relation to the direction of stem tilting, (A) - no tilting, (B) - upslope tilting, (C) - downslope tilting. 
suggests that the sampled alder are not older than 35 years. Of the 30 sampled alder trees, 10 were wounded in 2005, and 10 in 1996 (Fig 10). Most of the wounds which developed in 1996 and 2005 were big. The smaller wounds were mostly formed in 1992, 1994, 1998, 2001, 2003, 2008 and 2010 (Fig. 10). Eccentric tree-rings were found in 2006 among 11 trees, and in 1997 among nine trees. A smaller number of trees (from 1 to 6 ) recorded eccentric growth in 1992, 1994-1996, 1998-2005 and 2007-2011 (Fig. 10).

\section{DISCUSSION}

\section{An interpretation of dendrochronological dating, taking into account the occurrence of debris flows}

The dating wounds present in the alder stems and the years when eccentric growth occurred indicate that the alder trees under study reacted most strongly to debris flow stress in 2005 and 1996. A weaker reaction was recorded every 2-3 years, when a few scars (in 1-4 trees/year) and eccentric growth (in 1-6 years) were found. Results achieved through the application of dendrochronological methods suggest that we have dated two strong debris flows in 1996 and 2005, when many trees were wounded and tilted by transported boulders. We have also dated numerous debris flows every 2-3 years. However, during these events, a relatively small number of trees were wounded or slightly tilted. Our results suggest that these flows were much weaker compared with the flows in 1996 and 2005. Still, we cannot exclude the possibility that the energy of debris flows was diverse in space, in different parts of the fan under study. Therefore, the obtained dating results should only be analysed in relation to the area where the dendrochronological samples were taken. On the other hand, we have also acquired information from the local authorities on the large debris flows which occurred in the area under study in 2005. This suggests that the obtained dendrochronological ages are highly accurate.

When analysing debris flow occurrence in monsoon climate conditions, wound dating seems to be more precise when compared to eccentricity index calculation. Eccentric growth was usually recorded one year after scars were produced (and the debris flow event). The highest number of eccentric growth cases was recorded in 1997 and 2006. The eccentric growth of stems in reaction to events in 1996 and 2005 seems to be divided into two years. It started directly after tilting during the debris flow, but in the middle of a growing season. So eccentricity was recorded only in the second half of tree rings (i.e. the second half of the 1996 and 2005 rings). The first half of these rings developed under normal conditions. The general eccentricity of a ring is less pronounced than the eccentricity in the following year. One year after debris flow, any eccentric growth is fully visible (1997, 2006), because the trees were tilted from the very begin-

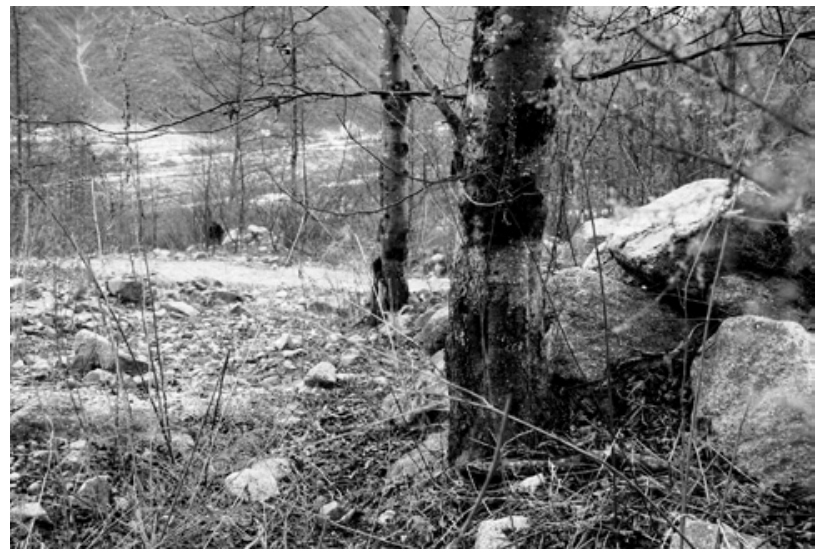

Fig. 9. Boulders captured by the stem of alder tree during a debris flow event.

Table 1. Maximal, minimal, and average boulder size at the 5 measuring points located along the debris flow tracks.

\begin{tabular}{cccc}
\hline $\begin{array}{c}\text { Measuring } \\
\text { points }\end{array}$ & $\begin{array}{c}\text { Minimal size } \\
\text { of boulders } \\
\text { (cm) }\end{array}$ & $\begin{array}{c}\text { Maximal size } \\
\text { of boulders } \\
\text { (cm) }\end{array}$ & $\begin{array}{c}\text { Average size } \\
\text { of boulders } \\
\text { (cm) }\end{array}$ \\
\hline 1 & 10 & 30 & 25 \\
\hline 2 & 5 & 40 & 25 \\
\hline 3 & 15 & 45 & 30 \\
\hline 4 & 60 & 110 & 85 \\
\hline 5 & 50 & 145 & 120 \\
\hline
\end{tabular}

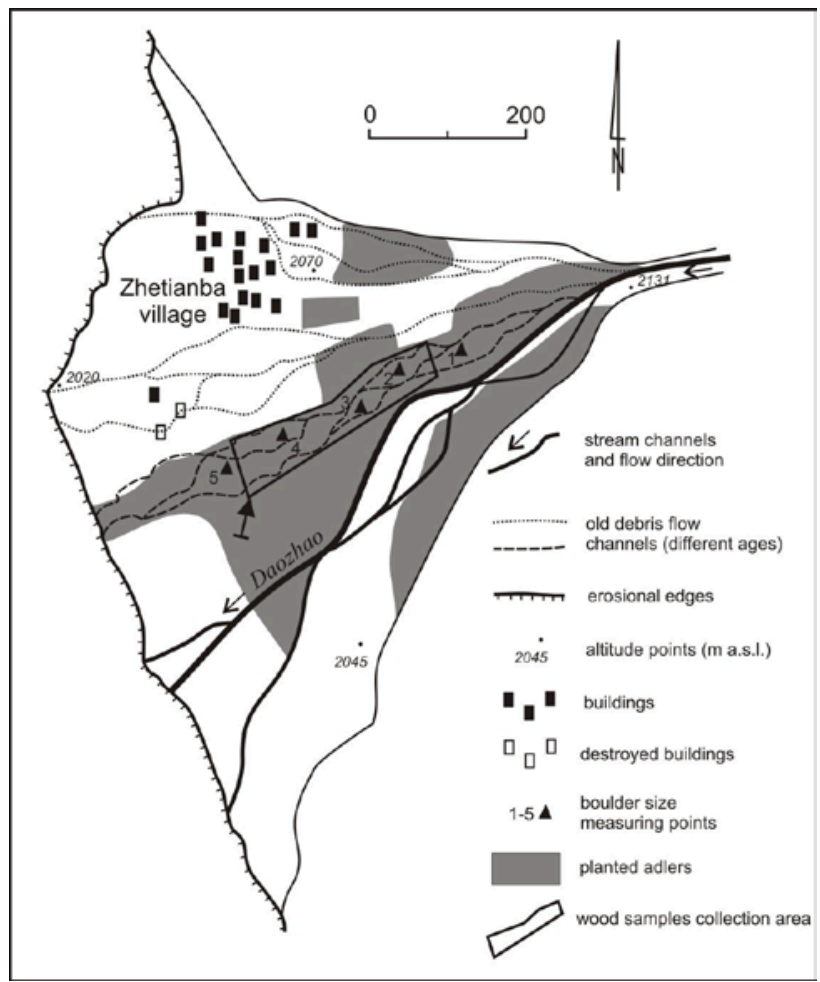

Fig. 10. The number of debris flow events recorded by tree-ring analyses, (A) - results of the dating of wounded alder stems, (B) - results of the dating using eccentric growth. 
ning of a growing season. The eccentricity which started in 1995 or 2005 continued into 1996 or 2006.

A comparison of results obtained using scars and eccentricity enabled us to confirm that debris flows in the study area probably occur during the growing season. A similar lagged reaction by trees to geomorphic events has also been described by Malik (2006). On the other hand, we cannot exclude the possibility that two or more debris flow episodes produced eccentric growth in alder trees over the course of one year. In such a case, the comparison of results obtained using scars and eccentricity may not have enabled us to find when the debris flow under study took place.

\section{The protective role of planted alder trees against the destructive effects of debris flow}

Most Alnus nepalensis specimens planted on the studied fan capture debris flow material and protect people and houses from debris flows. Alnus nepalensis is a species which prefers wet conditions for growth. Alder roots are well adapted to growth in anaerobic conditions, which is why they endure the stress connected with root systems buried by sediments delivered by debris flows. The large radial growth dynamics of the studied alders confirm that their location on the debris flow fan offers a good habitat for this species. The average width of annual rings is as much as $1.4 \mathrm{~cm}$. By way of comparison, alders growing in the riparian forests of Europe produce tree-rings with average widths not exceeding $1 \mathrm{~cm}$ (McVean, 1953). This means that the studied alders can very quickly reach a size large enough for the efficient capture of debris transported during flow events. Alnus nepalensis possesses the ability to quickly heal any wounds that are sustained and also the ability to develop suckers in the wounded parts of stems. Alder trees are also very plastic and can continue to grow when they are strongly tilted or bent. This means that the people living within the area endangered by debris flows probably chose alders as the trees to be planted in the zone where coarse grained sediments are delivered.

In the studied zone of the fan, debris flows slow down and lose more of their energy - in comparison to the debris flow gully located above - due to the decreasing slope inclination. Planting trees on the fan surface enables the efficient capture of debris and additionally slows down transported sediment. Only a few broken alders were found, which means that events during which the flow energy is high enough to destroy the stand are a rare occurrence.

It seems that in the case of small catchments, where debris flows pose less threat to planting, alder trees enable the protection of houses and fields from destruction by transported debris. Alders capturing sediment delivered from side-valleys reduce the energy of the massmovements which occur in the main valley. This should also limit any damage caused by debris flows in the areas located downstream of the delivery zone (e.g. the valley of the Yajiageng River, which is below the described Daozhao drainage basin). When debris flows are larger and develop in such locations as large post-glacial valleys, it is necessary to use more technically advanced systems of protection against mass-movements. One such system was introduced in the Minya Konka Massif, around $20 \mathrm{~km}$ south-east from the studied debris-flow. The technical solution is based on the installation of microphones in the upper part of the catchment. When a debris flow starts, the sounds connected with its occurrence are received below, where the tourist infrastructure has been developed. People are evacuated from the endangered area. Planting alder trees on debris flow fans enables the amount of sediment delivered to the main valleys, where the greatest damage is caused by mass movements, to be reduced.

\section{CONCLUSIONS}

1) Over the last 20 years, two major debris flow events occurred on the studied fan. Probably, smaller debris flow events also occurred every 2 to 3 years within the studied fan. This suggests there was a great frequency of debris flow development in the area under study.

2) $24 \%$ of the human-planted alders growing on the fan captured debris transported during flows. Alders growing near to the debris flow gully captured much bigger boulders than the alders growing far from the gully. This means that alder trees can efficiently protect houses against debris flows reaching the debrisflow fan.

3) Alnus nepalensis specimens are particularly predisposed to capturing sediment from debris flows. This is due to:

- their large radial growth dynamics - young trees, not exceeding 35 years old, are relatively large and can capture debris transported during debris flow episodes,

- their ability to grow in anaerobic conditions when their root systems are buried with debris,

- their ability to heal wounds rapidly by developing suckers in the damaged parts of stems,

- their ability to grow in conditions of strong stem tilting and bending.

\section{REFERENCES}

Bardou E and Delaloye R, 2004. Effects of ground freezing and snow avalanche deposits on debris flows in alpine environments. Natural Hazards and Earth System Sciences 4(4): 519-530, DOI 10.5194/nhess-4-519-2004.

Baumann F and Kaiser KF, 1999. The Multetta debris fan, eastern Swiss Alps: a 500-year debris flow chronology. Arctic, Antarctic, and Alpine Research 31(2): 128-134, DOI 10.2307/1552601.

Bollschweiler M, Stoffel M and Schlaeppy R, 2011. Debris-flood reconstruction in a prealpine catchment in Switzerland based on tree-ring analysis of conifers and broadleaved trees. Geografiska 
Annaler: Series A, Physical Geography 93(1): 1-15, DOI 10.1111/j.1468-0459.2011.00001.x.

Berti M and Simoni A, 2007. Prediction of debris flow inundation areas using empirical mobility relationships. Geomorphology 90(1-2): 144-161, DOI 10.1016/j.geomorph.2007.01.014.

Caine N, 1980. The rainfall intensity - duration control of shallow landslides and debris lows. Geografiska Annaler 22A: 23-27.

Chiarle M, Ianotti S, Mortara G and Deline P, 2007. Recent debris flow occurrences ssociated with glaciers in the Alps. Global and Planetary Change 56(1-2): 123-136, DOI 10.1016/j.gloplacha.2006.07.003.

Clark MK, Schoenbohm LM, Royden LH, Whipple KX, Burchfiel BC, Zhang X, Tang W, Wang E and Chen L, 2004. Surface uplift, tectonics, and erosion of eastern Tibet from large-scale drainage patterns. Tectonics 23(1): TC1020, DOI 10.1029/2002TC001397.

Conway SJ, Decaulne A, Balme MR, Murray JB and Towner MC, 2010. A new approach to estimating hazard posed by debris flows in the Westfjords of Iceland. Geomorphology 114(4): 556-572, DOI 10.1016/j.geomorph.2009.08.015.

Dai S, 2002. Forecast on trend of geological hazard control in Sichuan Province. The Chinese Journal of Geological Hazard and Control 13: 100-101.

Decaulne A, Sæmundsson B and Petursson A, 2005. Debris flow triggered by rapid nowmelt: a case study in the Gleidarhjallli area, northwestern Iceland. Geographical Analysis A 87A: 487-500.

Fielding EJ, 1996. Tibet uplift and erosion. Tectonophysics 260(1-3): 55-84, DOI 10.1016/0040-1951(96)00076-5.

Fiorillo F and Wilson RC, 2004. Rainfall induced debris flows in pyroclastic deposits, Campania (southern Italy). Engineering Geology 75(3-4): 263-289, DOI 10.1016/j.enggeo.2004.06.014.

Hrádek M and Malik I, 2007. Dendrochronological records of the floodplain morphology transformation of Desná River Valley in the last 150 years, the Hrubý Jeseník Mts. (Czech Republic). Moravian Geographical Reports 15(1): 2-10.

Ishikawa Y, Kawakami S, Morimoto Ch and Mizuhara K, 2003. Suppression of Derbis movement by forests and damage to forests by debris deposition. Journal of Forest Research 8(1): 37-47, DOI 10.1007/s103100300004.

Kotarba A, 1992. High-energy geomorphic events in the polish Tatra Mountains. Geographical Analysis 74A: 121-131.

Lancaster S and Hayes S, 2003. Effects of wood on debris flow runout in small mountain watersheds. Water Resources Research 39(6): 1168, DOI 10.1029/2001WR001227.

Leber D, Holawe F and Häusler H, 1995. Climatic classification of the Tibet Autonomous Region using multivariate statistical methods. GeoJournal 37(4): 451-473, DOI 10.1007/BF00806934.

Li Z, He Y, Yang X, Theakstone WH, Jia W, Pu T, Liu Q, He X, Song B, Zhang N, Wang S and Du J, 2010a. Changes of the Hailuogou glacier, Mt. Gongga, China, against the background of climate change during the Holocene. Quaternary International 218(1-2): 166-175, DOI 10.1016/j.quaint.2008.09.005.

Li Z, He Y, He X, Pu T, Jia W, He X, Pang H, Zhang N, Liu Q, Wang S, Zhu G, Wang S, Chang L, Du J and Xin H, 2010b. Changes of climate, glaciers and runoff in China's monsoonal temperate glacier region during the last several decades. Quaternary International 218(1-2): 13-28, DOI 10.1016/j.quaint.2009.05.010.

Lin C, Shie C, Yuan B, Shieh Y and Lee S, 2003. Impact of Chi-Chi earthquake on the occurrence of landslides and debris flows: example from the Chenyulan River watershed, Nantou, Taiwan. Engineering Geology 71(1-2): 49-61, DOI 10.1016/S00137952(03)00125-X.

Lopez-Saez J, Corona C, Stoffel M, Gotteland A, Berger F and Liebault F, 2011. Debris flow activity in abandoned channels of the Manival torrent reconstructed with LiDAR and tree-ring data. Natural Hazards and Earth System Sciences 11(5): 1247-1257, DOI 10.5194/nhess-11-1247-2011.

McVean DN, 1953. Alnus glutinosa (L.), (A. rotundifolia Stokes). Journal of Ecology 41: 447-465.

Malik I, 2004. The influence of riparian trees on meandering floodplain and riverbed transformation - The case of the Mała Panew River (Opole Plain). Przeglad Geograficzny 76: 345-360, (in Polish).
Malik I, 2006. Contribution to understanding the historical evolution of meandering rivers using dendrochronological methods: example of the Mała Panew River in southern Poland. Earth Surface Processes and Landforms 31(10): 1227-1245, DOI 10.1002/esp.1331.

Malik I and Matyja M, 2008. Bank erosion history on a mountain stream determined by means of anatomical changes in exposed tree roots over the last 100 years (Bílá Opava River - Czech Republic). Geomorphology 98(1-2): 126-142, DOI 10.1016/j.geomorph.2007.02.030.

Malik I and Owczarek P, 2009. Dendrochronological records of debris flow and avalanche activity in a mid - mountain forest zone (eastern Sudetes - central Europe). Geochronometria 34: 57-66, DOI 10.2478/v10003-009-0011-7.

Malik I and Wistuba M, 2012. Dendrochronological methods for reconstructing mass movements - An example of landslide activity analysis using tree-ring eccentricity. Geochronometria 39(3): 180196, DOI 10.2478/s13386-012-0005-5.

Matyja M, 2007. The Significance of Trees and Coarse Woody Debris in Shaping the Debris Flow Accumulation Zone (North Slope of the Babia Góra Massif, Poland). Geographia Polonica 80: 83-101.

May ChL, 2002. Debris flow through different forest age classes in the Central Oregon Coast Range. Journal of the American Water Resources Association 38(4): 1097-1113, DOI 10.1111/j.17521688.2002.tb05549.x.

Migoń P, Pánek T, Malik I, Hrádecký J, Owczarek P and Šilhán K, 2010. Complex landslide terrain in the Kamienne Mountains, Middle Sudetes, SW Poland. Geomorphology 124(3-4): 200-214, DOI 10.1016/j.geomorph.2010.09.024.

Miller and Burnett, 2008. A probabilistic model of debris-flow delivery to stream channels, demonstrated for the Coast Range of Oregon, USA. Geomorphology 94(1-2): 184-205, DOI 10.1016/j.geomorph.2007.05.009.

Procter E, Bollschweiler M, Stoffel M and Neumann M, 2011. A regional reconstruction of debris-flow activity in the Northern Calcareous Alps, Austria. Geomorphology 132(1-2): 41-50, DOI 10.1016/j.geomorph.2011.04.035.

Reid ME, Nielsen HP and Dreiss SJ, 1988. Hydrologic factors triggering a shallow hillslope failure. Bulletin of the International Association of Engineering Geology 25: 349-361.

Stoffel MI, Conus D, Grichting M, Raetzo H, Gärtner H and Monbaron M, 2005. 400 Years of Debris-Flow Activity and Triggering Weather Conditions: Ritigraben, Valais, Switzerland. Antarctic and Alpine Research 37: 387-395, DOI 10.1657/15230430(2005)037[0387:YODAAT]2.0.CO;2.

Stoffel M, 2010. Magnitude-frequency relationships of debris flows A case study based on field surveys and tree-ring records. Geomorphology $\quad 116(1-2): \quad 67-76, \quad$ DOI 10.1016/j.geomorph.2009.10.009.

Šilhán K and Pánek T, 2010. Fossil and recent debris flows in mediumhigh mountains (Moravskoslezské Beskydy Mts, Czech Republic). Geomorphology 124(3-4): 238-249,

DOI 10.1016/j.geomorph.2010.03.026.

Šilhán K, 2012. Frequency of fast geomorphological processes in highgradient streams: case study from the Moravskoslezské Beskydy Mts (Czech Republic) using dendrogeomorphic methods. Geochronometria 39(2): 122-132, DOI 10.2478/s13386-012-0002-8.

Šilhán K, Pánek T and Hrádecký J, 2012. Tree-ring analysis in the reconstruction of slope instabilities associated with earthquakes and precipitation (the Crimean Mountains, Ukraine). Geomorphology 173-174: 174-184, DOI 10.1016/j.geomorph.2012.06.010.

Su Z and Shi Y, 2002. Response of monsoonal temperate Glacier to global Warming Since the Little Ice Age. Quaternary International 97-98: 123-131, DOI 10.1016/S1040-6182(02)00057-5.

Tang C, Zhu J, Qi X and Ding J, 2011. Landslides induced by the Wenchuan earthquake and the subsequent strong rainfall event: A case study in the Beichuan area of China. Engineering Geology 122(1-2): 22-33, DOI 10.1016/j.enggeo.2011.03.013.

Tang C, Van Asch TWJ, Chang M, Chen GQ, Zhao XH and Huang XC 2012a. Catastrophic debris flows on 13 August 2010 in the Qingping area, southwestern China: The combined effects of a strong 
earthquake and subsequent rainstorms. Geomorphology 139-140: 559-576, DOI 10.1016/j.geomorph.2011.12.021.

Tang C, Zhu J, Chang M, Ding J and Qi X, 2012b. An empiricalstatistical model for predicting debris-flow runout zones in the Wenchuan earthquake area. Quaternary International 250: 63-73, DOI 10.1016/j.quaint.2010.11.020.

Tie Y, 2013. Prediction of the run-out distance of the debris flow based on the velocity attenuation coefficient. Natural Hazards 65(3): 1589-1601, DOI 10.1007/s11069-012-0430-z.

Yan Y and Yue C, 2004. Discussion on the characteristics and countermeasures for the geological hazard in Sichuan Province. The Chi- nese Journal of Geological Hazard and Control 15: 123-127, (in Chinese).

Zielonka T, Ciapała S, Malina P and Piątek G, 2009. Coarse woody derbis in mountain streams and their influence on geomorphology of channels in the Tatra Mts. Landform Analysis 10: 134-139.

Zielonka T and Dubaj N, 2010. A tree-ring reconstruction of geomorphologic disturbances in cliff forests in the Tatra Mts. Landform Analysis 11: 43-48

Zielski A and Krąiec M, 2004. Dendrochronologia. PWN, Warszawa. (in Polish). 